ORIGINAL PAPER

\title{
Nuclear changes in pathogen-infected tomato roots
}

\author{
G. Lingua ${ }^{1}$, G. D’Agostino ${ }^{2}$, A. Fusconi ${ }^{3}$ and G. Berta ${ }^{1}$
}

'Dipartimento di Scienze e Tecnologie Avanzate dell'Università del Piemonte Orientale, 'A. Avogadro', corso Borsalino 54, 15100 Alessandria, Italy; ${ }^{2}$ Istituto di Fitovirologia applicata del CNR, strada delle Cacce 73, Torino, Italy ${ }^{3}$ Dipartimento di Biologia Vegetale dell’Università di Torino, viale Mattioli 25, Torino, Italy.

Accepted: 14/12/00

Key words: flow cytometry, light and electron microscopy, host nucleus, Lycopersicon esculentum, Phytophthora nicotianae var. parasitica, phytoplasmas, endoreduplication

\section{SUMMARY}

We have investigated nuclear changes induced in tomato (Lycopersicon esculentum) root plants by two different pathogens, a phytoplasma of the stolbur group and the soil-borne fungus Phytophthora nicotianae var. parasitica, using light and electron microscopy as well as flow cytometry. Our results show that both pathogens strongly influenced nuclear structure, causing pyknosis and chromatolysis, and induced variations in proportion of nuclear populations with different DNA content, increasing the $2 \mathrm{C}$ and decreasing the $4 \mathrm{C}$ nuclear populations. These latter results suggest a block of the endoreduplication process in the presynthetic phase of the host cell cycle. Moreover, in pathogen-infected roots, nuclei of the same DNA content were less fluorescent, and therefore had a lower DNA content, compared to those of controls, as confirmed by morphological analyses. Our findings suggest that different stimuli may evoke similar nuclear changes, and confirm the usefulness of flow cytometry as a tool to recognize the stress conditions related to the presence of a pathogen.

Abbreviations: DAPI - 4',6-diamidino-2-phenylindole

\section{INTRODUCTION}

Nuclear changes induced in plant host cells by pathogens (fungi, viruses, bacteria and nematodes) have generally been well described, but little information is available about the quantitative variations of DNA induced by the infection (Baluska et al. 1995). High percentages of polyploid cells and high levels of ploidy are common among plants with a small DNA content per genome (Grif, 2000). Polyploidy has been thoroughly studied in understanding the significance of DNA amount per genome in plant biosystematics (Grif, 2000), and during differentiation (D'Amato, 1998; Traas et al, 1998); less information exists on the effects of environmental factors on ploidy levels, although some factors (among which light) are known to influence them (Gendreau et al., 1998).

Phytoplasmas are prokaryotes, obligate parasites, belonging to the class Mollicutes; their presence has been well documented in the shoot phloem tissue of many plants of economic interest including tomato (Lisa et al., 1982). Their presence and effects on roots have been shown by a relatively small number of authors (Sinclair and Griffiths 1992; Cousin 1995, Lherminier and Boudon-Padieu 1996). 
In this paper we have analysed morphological and quantitative nuclear changes induced in the roots of tomato (Lycopersicon esculentum) by a phytoplasma of the stolbur group (Lee et al., 1998; Seemüller et al., 1998) and by a soil-borne fungus, Phytophthora nicotianae var. parasitica, using light and electron microscopy and flow cytometry. Tomato nuclei have a low DNA amount $(2 \mathrm{C}=2 \mathrm{pg})$, and they should therefore be very plastic (D'Amato, 1998); moreover, in the roots only the meristematic apical cells are consistently diploid, while in the differentiated portion of the roots there are three levels of DNA content (2C, 4C, 8C) (Fusconi et al., 1997; Lingua et al., 2001; Berta et al., 2001) that could be influenced by the presence of a pathogen.

\section{MATERIAL AND METHODS}

\section{Plant growth and infection}

Seeds of Lycopersicon esculentum cv Early Mech were germinated in Petri dishes on moist filter paper for 3-4 days. The seedlings were then transferred to quartz sand $(0.5 \mathrm{~mm}$ coarse grade) in 1.5 1 polyethylene pots. The pots were placed in growth chambers, 16/8 hours light/dark photoperiod, $24 / 22^{\circ} \mathrm{C}$ light/dark thermoperiod, $130 \mathrm{mmol} . \mathrm{m}^{-2} \mathrm{~s}^{-1}$ light irradiance at pot height and watered 3 days a week (alternate days) each with $100 \mathrm{ml}$ of half strength Long Ashton nutrient solution, according to Trotta et al., 1996.

Three weeks after sowing, ten plants were grafted with scions of tomato infected with STOL-S1 (Minucci and Boccardo 1997), a phytoplasma of the stolbur group; ten were grown ungrafted and ten grafted with healthy scions, as controls. All the plants were harvested 60 days after pathogen infection, when disease symptoms were clear, and their root systems were processed for light and electron microscopy and flow cytometry.

In another experiment, three weeks after sowing nine plants were inoculated with 100,000 zoospores of Phytophthora nicotianae var. parasitica Breda De Haar (isolate 201, subsequently referred to as $P$. parasitica); other plants of the same batches remained uninoculated. Plants were harvested 10 days post inoculation (again when disease symptoms were evident) and processed as above.

\section{Light and electron microscopy}

Small segments were sampled from the adventitious roots of 3 plants per treatment. The segments were cut at about $6 \mathrm{~cm}$ from the apex, then fixed in $2.5 \%$ glutaraldehyde in $0.1 \mathrm{M}$ phosphate buffer $(\mathrm{pH} 7)$ for $3 \mathrm{~h}$ at room temperature, post-fixed in $1 \% \mathrm{OsO}_{4}$ in the same buffer for $2 \mathrm{~h}$ at room temperature, dehydrated and embedded in LR White resin at $60^{\circ} \mathrm{C}$. Semithin and thin sections were cut with a Reichert Ultracut E ultramicrotome. The former were stained with $1 \%$ toluidine blue in $1 \%$ sodium tetraborate and examined under a light microscope. The latter were contrast-stained with $0.5 \%$ uranyl acetate and lead citrate (Reynolds, 1963), and examined under a Philips CM 10 electron microscope.

\section{Evaluation of phytoplasma and $P$. parasitica infections}

To confirm the presence of phytoplasmas in the roots, semithin and thin sections were observed by light and electron microscopy, respectively.

$P$. parasitica infection was checked microscopically on semithin and hand cut sections. An immunocytological analysis was performed using polyclonal antibodies against $P$. megasperma (kindly provided by E. Schmelzer, MPI, Cologne), according to Cordier et al. (1996). Indirect immunolabelling with alkaline phosphatase conjugated secondary antibody was used to visualize $P$. parasitica hyphae in $4 \%$ paraphormaldehyde pre-fixed whole root fragments.

\section{Flow cytometry}

Three two-months old tomato plants infected and uninfected by phytoplasmas, and six one month old tomato plants infected and uninfected by $P$. parasitica were processed for flow cytometry. Nuclei were extracted from whole root systems, after the removal of their apices. The roots where chopped with a razor blade in a few drops of extraction buffer $(0.1 \mathrm{M}$ citric acid, $0.5 \%$ Tween $20)$. Nuclei were extracted after 30 min incubation in this buffer by filtering through a $20 \mu \mathrm{m}$ nylon mesh. All the steps were carried out on ice. The samples were fixed by adding two volumes of icecold ethanol-acetic acid (3:1) to one volume of nuclei suspension and stored at $-20^{\circ} \mathrm{C}$.

Two $\mathrm{ml}$ of the fixed samples were centrifuged at $500 \mathrm{~g}$ on a $1 \mathrm{M}$ sucrose cushion in order to elimi- 
nate the fixative and reduce the debris. The pellet was resuspended in $500 \mathrm{ml}$ PBS, the nuclei were counted and diluted with PBS buffer (phosphatebuffered saline, prepared according to Sambrook et al. 1989) to adjust their concentration to $5 \times 10^{5}$ $\mathrm{ml}^{-1}$. Due to the severe damage inflicted by P. parasitica to the roots, the number of nuclei was lower than from phytoplasma-infected roots; therefore the six nuclear suspensions were pooled to form just one sample. They were stained with 4', 6diamidino-2-phenylindole (DAPI, Sigma) at saturating concentration $(5.6 \mu \mathrm{M})$.

Polyscience Fluorsbryte beads $(4.2 \mu \mathrm{m})$ were used as a standard to calibrate the instrument and to check the instrument stability. Therefore, the beads were run before and after each sample analysis in order to compare the intensities of fluorescence of the various samples.

A mercury arc lamp was used in conjunction with BG1 and UG1 filters and a TK420 dichroic mirror to select the exciting wavelength (UV) of a Partec PAS-IIIi flow cytometer (Partec GmbH, Munster, Germany). DAPI fluorescence was detected using a GG415 barrier filter. All the filters and dichroic mirrors were provided by the flow cytometer producer. Data were acquired and analyzed with Parteclist, the software included in the instrument package. All the data on phytoplasmas were compared with a Student t-test, using a $t$ value with a $95 \%$ confidence level $(\mathrm{t}=2,776$, d.f. $=4)$. A total of almost 28,000 nuclei from the phytoplasma-infected roots and of over 24,000 from control roots were analyzed.

The differences between $P$. parasitica infected and uninfected roots were evaluated by calculating standard errors and limits of confidence at $99 \%$ $(t=2.576$; d.f. $=\infty)$ for each fluorescence value. In addition, the data regarding the same ploidy levels from the two different treatments were compared with a "u test" (a.k.a. " $z$ test") for binomial distributions. In this way we tested the differences between the percentages of $2 \mathrm{C}$, then of $4 \mathrm{C}$ and finally of 8C. A total of about 3,800 nuclei from $P$. parasitica-infected roots and of more than 6,200 from control roots were analyzed.

Flow cytometry results were displayed on histograms. On the y-axis was displayed the number of nuclei, on the x-axis the intensity of fluorescence. Hence, the nearer a peak was to the origin, the lower the fluorescence, and viceversa.

\section{RESULTS}

\section{Phytoplasma infected roots}

The phytoplasmas were observed in tomato roots, which as a consequence showed extensive necrosis. They were present in every root zone checked, inducing senescence in the phloem elements (Figs. 1a, b, c), in the companion cells and in the surrounding tissues, where cell walls were thin and distorted (Figs. 1a, 2b).

The nuclei of the control (uninfected) roots were elongated and showed the usual chromocentric features (Fig. 2a), i.e. decondensed, diffuse chromatin and only small patches of condensed chromatin (chromocentres).

The nuclei of infected companion cells were elongated, and in some cases, partly fragmented. Some showed lysed chromatin and very large, irregularly arranged chromocentres at their periphery (Fig. 2b). Even further degraded nuclei were also present, with very loosely packed chromatin, in senescing tissues other than the phloem, such as cortex (Fig. 2c). These forms of nuclear degeneration can, according to Woolhouse (1984), be termed "chromatolysis".

\section{P. parasitica -infected roots}

P. parasitica induced massive necrosis in the roots. Immunocytological analyses showed the presence of $P$. parasitica in the apex (Fig. 3a) and in the differentiated zone, where hyphae frequently appeared to penetrate through root hairs (Fig. 3b), but also through epidermal cells (Fig. 3c). Hyphae grew between and into the cortex cells (Fig 3c), to reach the central cylinder.

The presence of $P$. parasitica in root tissues resulted in death and necrosis, not only of invaded cells, but also of adjacent uninfected cortical cells, that were plasmolytic, with distorted and thin walls, autophagic vacuoles, and senescent nuclei. The latter were in lateral position, chromatolytic or pyknotic, generally rounded, sometimes lobed (Fig. 3c). The most affected nuclei had clear rings around the nucleolus, caused by degradation and loss of chromatin (Fig. 2d).

\section{Flow cytometry analyses}

Both pathogens influenced distribution of the nuclei in the three populations, significantly increasing that with the lowest DNA content, i.e. 2C nuclear population, and decreasing the $4 \mathrm{C}$ nuclear 


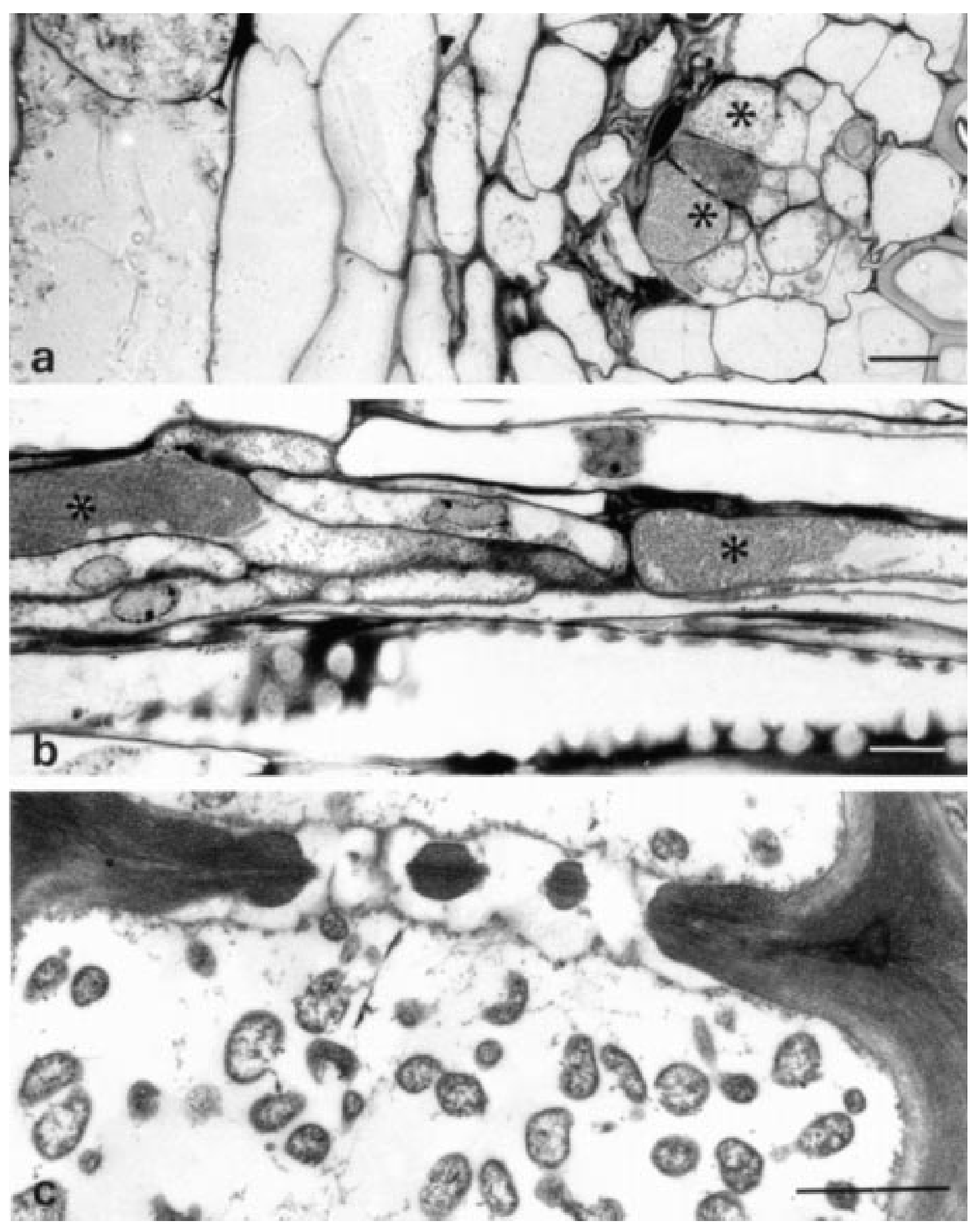


Table I

Percentage of nucleus populations with different DNA content $(2 \mathrm{C}, 4 \mathrm{C}, 8 \mathrm{C})$ in tomato roots \pm standard errors. PTP $=$ phytoplasma; asterisk $(*)$ indicates significant differences according to the Student t-test, with $95 \%$ confidence limits

\begin{tabular}{cccc}
\hline DNA content & control plants & PTP infected plants & t \\
\hline $2 \mathrm{C}$ & $21.53 \pm 1.72$ & $35.58 \pm 4.12$ & -3.145 \\
$4 \mathrm{C}$ & $72.06 \pm 2.30$ & $60.78 \pm 3.82$ & 2.528 \\
$8 \mathrm{C}$ & $6.41 \pm 1.49$ & $3.63 \pm 0.33$ & 1.823 \\
\hline
\end{tabular}

Table II

Percentage of nucleus populations with different DNA content $(2 \mathrm{C}, 4 \mathrm{C}, 8 \mathrm{C})$ in tomato roots \pm standard errors. $\mathrm{Pp}=P$. parasitica; asterisk (*) indicates significant differences according to the Student $\mathrm{t}$-test, with $95 \%$ confidence limits

\begin{tabular}{cccc}
\hline DNA content & control plants & Pp infected plants & $\mathbf{u}$ \\
\hline 2C & $16.723 \pm 0.005$ & $20.453 \pm 0.006$ & $4.619^{*}$ \\
4C & $80.324 \pm 0.005$ & $76.410 \pm 0.007$ & $4.585^{*}$ \\
8C & $2.953 \pm 0.002$ & $3.137 \pm 0.003$ & 0.517 \\
\hline
\end{tabular}

population. No difference was found between $8 \mathrm{C}$ nuclei in any of the two comparisons between pathogen infected roots and controls (Fig. 4; Tables I and II).

Saturating DAPI staining caused lower fluorescence in pathogen infected root nuclei of the same ploidy levels, compared to those extracted from control roots, i.e. $2 \mathrm{C}$ and $8 \mathrm{C}$ nuclei extracted from phytoplasma-infected roots were significantly less florescent than 2C and 8C nuclei of controls, respectively (Fig. 4; Table III). Comparing $P$. parasitica-infected plants and their controls, all the differences were significant (Table IV).

\section{DISCUSSION}

We have investigated nuclear changes in roots of tomato plants infected with two different pathogens by light and transmission electron microscopy and by flow cytometry. For both pathogens we observed nuclear chromatolysis and pyknosis, variations in the proportions of nuclear populations, and a lower intensity of fluorescence of pathogen-infected plant nuclei at some levels of DNA content. These results have been obtained in spite of the different ages at which the plants from the two different experimental systems were analyzed, due to the different times required for the development of the two pathogenic infections.

Light and electron microscopy results on pathogen-infected plant nuclei were not different from others in the literature on senescing nuclei (Woolhouse, 1984; Fusconi et al., 1999) and showed highly degraded chromatin, resulting in chromatolysis and pyknosis. These features are probably caused by a loss of DNA or the integrity of DNA, as confirmed by the lower fluorescence observed. We have previously shown that the nuclei of tomato plants infected with $P$. parasitica

Fig. 1 - Sections of tomato adventitious roots infected by stolbur phytoplasma. (a-b) Light micrographs showing sieve elements filled with dense particles (*) identified by electron microscopy as phytoplasmas. (a) In cross section, in which thin and distorted walls are visible (b) in longitudinal section; note the presence of nuclei with different degree of chromatolysis (arrows). Bars represent $10 \mu \mathrm{m}$. (c) Electron micrograph showing many phytoplasmas, the amoeboid-shaped bodies, in a sieve element. Bars represent $1 \mu \mathrm{m}$. 

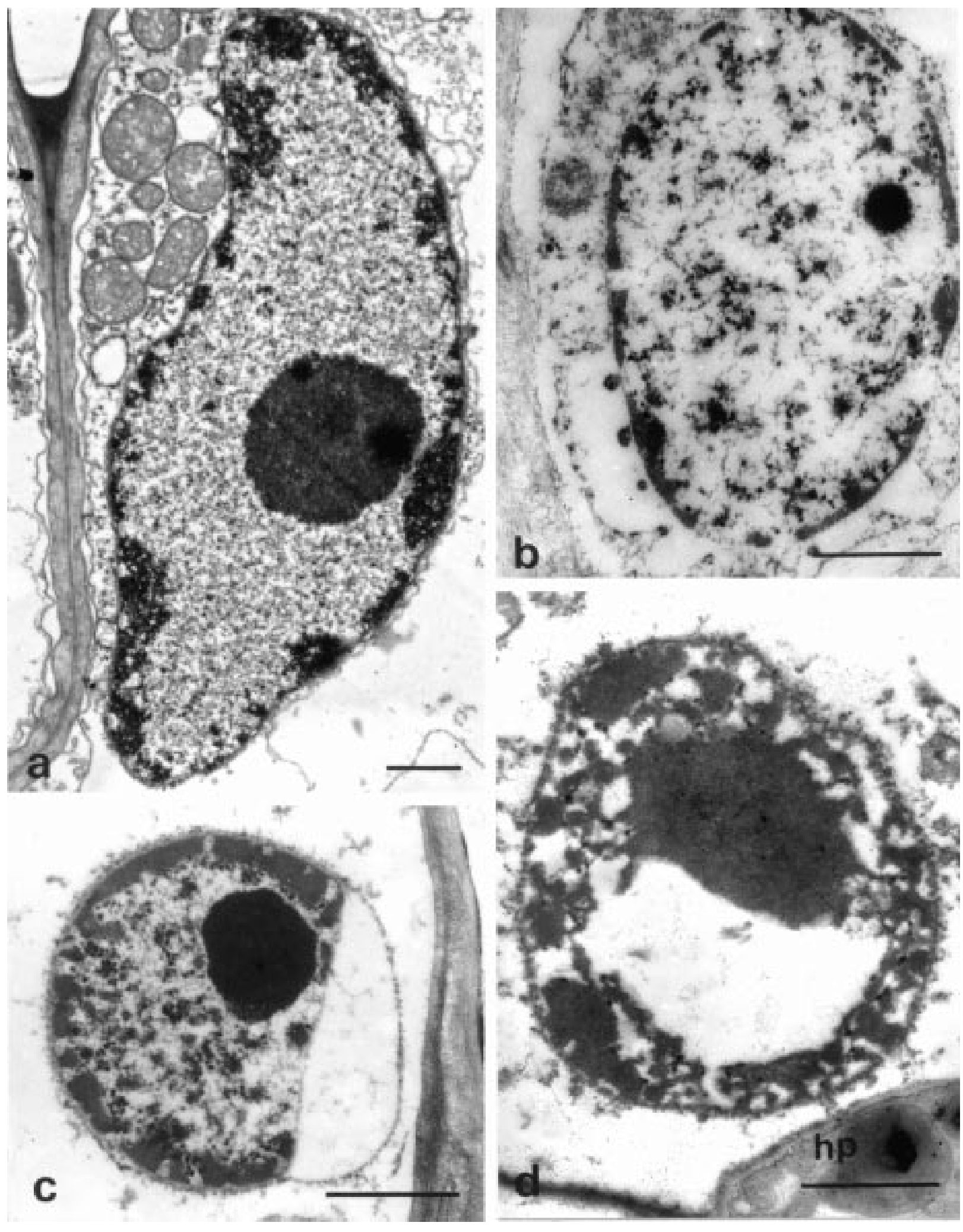
Fig. 3 - Light micrographs of Lycopersicon esculentum adventitious roots infected with Phytophthora parasitica after immunolocalization $(\mathbf{a}, \mathbf{b})$ or toluidine blue staining (c). (a) A root apex observed in toto ; the cap is deeply stained for the presence of the fungus. (b) A fungal hypha $(*)$ penetrating the root through a root hair. (c) Semi-thin section of a differentiated zone; fungal hyphae are clearly visible penetrating the root through epidermal cells and spreading between cortical cells. Bars represent $10 \mu \mathrm{m}$.

are less accessible to propidium iodide than those of uninfected plants (Lingua et al., 1996). These results, together with the present ones, are in agreement with the findings of O'Brien et al. (1998), who have shown a large decrease in fluorescence intensity of propidium iodide-stained nuclei in senescing plant cells; explained as a possible apoptosis-like pathway, as has already been shown in pathogen infected plants (reviewed by Pennell and Lamb, 1997).

The lower percentages of $4 \mathrm{C}$ and $8 \mathrm{C}$ nuclear populations and significantly higher $2 \mathrm{C}$ nuclear populations observed in pathogen-infected roots point out the plasticity of the genome of tomato as has been shown in plants infected by the arbuscular mycorrhizal fungus Glomus mosseae. In Glomus mosseae, however, a higher percentage of $8 \mathrm{C}$ nuclei has been observed, and explained by polyploidization (Berta et al., in press). The effects induced by pathogens may therefore be different from those induced by symbionts: infact, an increase of DNA quantity has already been reported not only in mycorrhizae, but also in the host nuclei of legumes when infected by rhizobia, though the results need further investigation (Brewin, 1991).

The increases in $2 \mathrm{C}$ nuclear populations should not be ascribed to larger cribro-vascular cambium tissues or to other root morphogenetic modifications: tomato plants infected with $P$. parasitica had thinner roots than controls (Fusconi et al., 1999), as did phytoplasma-infected roots, whose mean diameter was significantly lower than that of controls (phytoplasmas: $\mathrm{mm} 0.77 \pm 0.04$; controls: $\mathrm{mm} 1.12 \pm 0,07)$. In addition, no difference was found between the percentages of nuclear populations extracted from lateral or from adventitious roots (Berta, unpublished results).

The present findings suggest a block of endoreduplication in the presynthetic phase of the cell cycle, leading to an increase in $2 \mathrm{C}$ nuclear populations in pathogen-infected roots, in agreement with previous results obtained by static cytometry (Fusconi et al. 1997). Biotic stresses, such as those induced by pathogens, could possibly control the step at which cells exit the mitotic cycle and become committed to rounds of endoreduplication, as has been shown for at least one abiotic stress, water deficiency (Artlip et al. 1995). In this case, carbohydrate metabolism and

Fig. 2 - Electron micrographs of adventitious root nuclei in Lycopersicon esculentum. (a) A control cortical cell nucleus, in which small patches of condensed chromatin (chromocentres) are visible at the periphery. (b, c) nuclei from phytoplasma-infected roots. (b) Strongly chromatolytic nucleus in a companion cell. (c) A cortical cell nucleus in which both chromatolysis (on the right) and pyknosis are evident. (d) A nucleus with dramatic chromatolysis in a cortical cell in which a Phytophthora parasitica hypha is visible (hy). Bars represent $1 \mu \mathrm{m}$. 


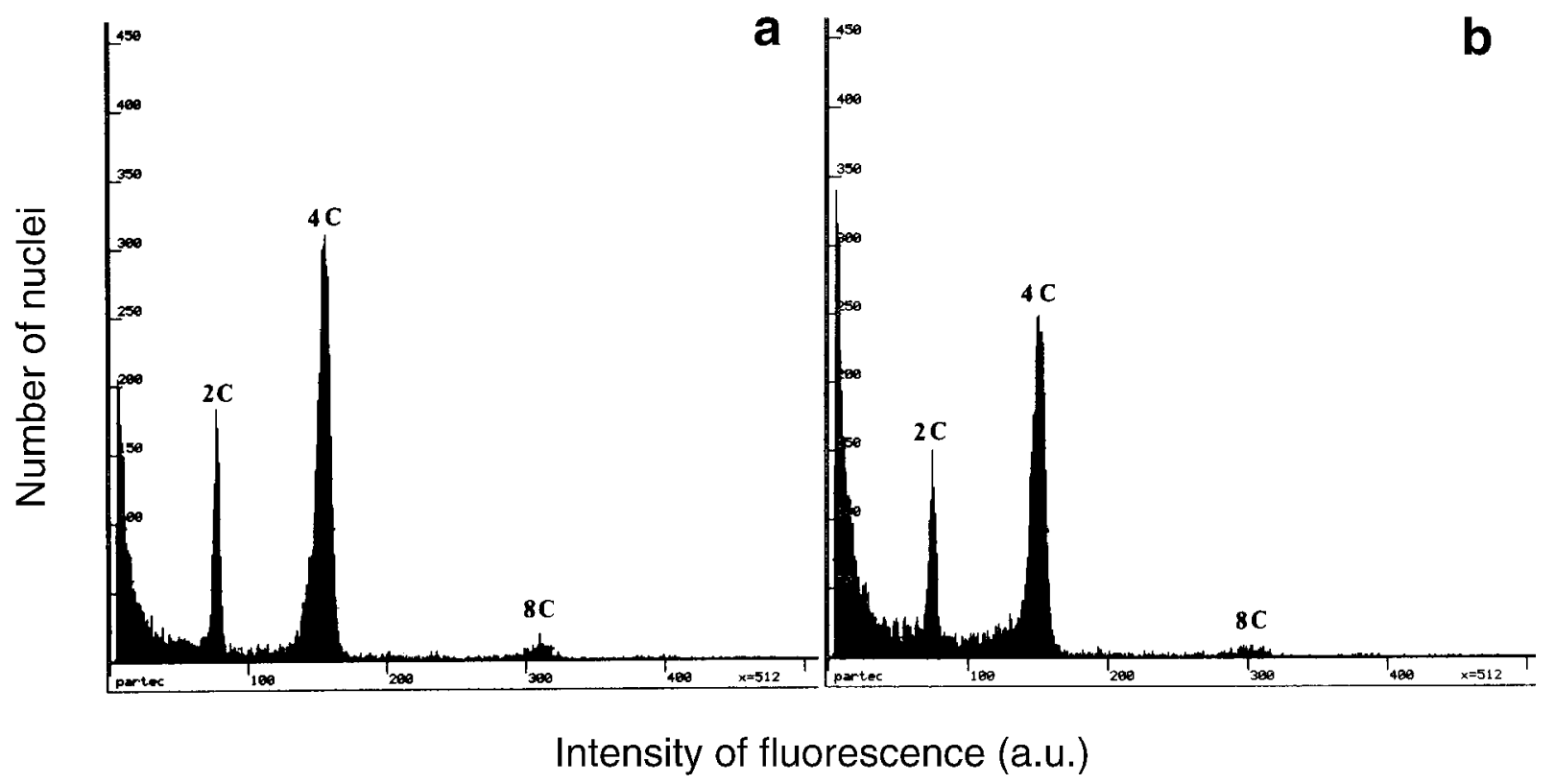

Fig. 4 - Flow cytometry histograms of DAPI-stained nuclei extracted from tomato roots. (a) Control plants, (b) phytoplasmainfected plants. On the x-axis the intensity of fluorescence, measured in arbitrary units; on the y-axis the number of nuclei. In each graph three peaks, corresponding to $2 \mathrm{C}, 4 \mathrm{C}$ and $8 \mathrm{C}$ nuclear populations, are visible. The mean fluorescence intensity of the peaks of the phytoplasma-infected plants were always lower than those of the control plants (i.e., they were nearer to the origin on the $\mathrm{x}$-axis).

translocation could be involved. $P$. parasitica, as other fungal pathogenic invaders, should tend to increase the amount of carbohydrate transported to infected root zones (Isaac, 1992). After phytoplasma infection, the presence of the microorganisms in the phloem tubes impairs the transport pathway, and, as a result, the supply of photosynthate to root tissues is reduced (Catlin, 1975; Braun and Sinclair, 1978; Lepka et al., 1999).

Our results indicate that different stimuli may evoke a similar senescence pattern and allowed us to consider flow cytometry as a new tool in inves- tigating the physiological condition of a root system. In fact, it allows detection in the host nucleus not only of DNA loss (Lingua et al. 1996), but also of DNA quantity variations, which are strongly influenced by the presence of pathogens.

\section{ACKNOWLEDGEMENTS}

This work was partly supported by Italian MURST funds. The authors are very grateful to Dr. N. Massa for her help in growing and treating the plants.

Table III

Mean fluorescence intensity of DAPI stained nuclei in tomato roots \pm standard errors. PTP $=$ phytoplasma; asterisk (*) indicates significant differences according to the Student t-test, with $95 \%$ confidence limits

\begin{tabular}{cccc}
\hline DNA content & control plants & Pp infected plants & t \\
\hline 2C & $75.67 \pm 1.48$ & $66.67 \pm 1.59$ & $4.142^{*}$ \\
$4 \mathrm{C}$ & $148.33 \pm 4.00$ & $133.33 \pm 4.23$ & 2.577 \\
$8 \mathrm{C}$ & $298.00 \pm 8.98$ & $264.67 \pm 7.73$ & $2.815^{*}$ \\
\hline
\end{tabular}


Table IV

Mean fluorescence intensity of DAPI stained nuclei in tomato roots \pm the limits of confidence calculated at 99\% (t 2.576; d.f. $=\infty$ ). Standard errors are in breakets. $\mathrm{Pp}=$ P. parasitica: All differences were significant, according to the calculated confidence limits

\begin{tabular}{ccc}
\hline DNA content & control plants & Pp infected plants \\
\hline 2C & $77.50 \pm 0.34(0.13)$ & $74.00 \pm 0.14(0.06)$ \\
4C & $153.00 \pm 0.24(0.09)$ & $149.50 \pm 0.15(0.06)$ \\
$8 \mathrm{C}$ & $309.00 \pm 0.43(0.17)$ & $301.00 \pm 0.65(0.25)$ \\
\hline
\end{tabular}

\section{REFERENCES}

Artlip T.S., Madison J.T. and Setter T.L.: Water deficit in developing endosperm of maize: cell division and nuclear DNA endoreduplication. Plant, Cell and Envir., 18, 10341040, 1995.

Baluska F., Bagigàlovà K., Oud J.L., Hauskrecht M. and Kubica S.: Rapid reorganization of microtubular cytoskeleton accompanies early changes in nuclear ploidy and chromatin structure in postmitotic cells of barley leaves infected with powdery mildew. Protoplasma, 185, 140-151, 1995.

Berta G., Fusconi A., Sampò S., Lingua G., Perticone S., and Repetto O.: Polyploidy in tomato roots as affected by arbuscular mycorrhizal colonization. Plant and Soil 226, 37-44, 2001.

Braun E.J., and Sinclair W.A.: Translocation in phloem necrosis-diseased American elm seedlings. Phytopathology, 68, 1733-1737, 1978.

Brewin N.J.: Development of the legume root nodule. Annu. Rev. Cell Biol. 7, 191-226, 1991.

Cordier C., Gianinazzi S., and Gianinazzi-Pearson V.: Colonization patterns of root tissues by Phytophthora nicotianae var. parasitica related to reduced disease in mycorrhizal tomato. Plant Soil 185, 223-232, 1996.

Cousin M.T.: Phytoplasmes et phytoplasmoses. Agronomie 15, 245-264, 1995

Catlin P.B., Olsson E.A., and Beutel J.A.: Reduced translocation of carbon and nitrogen from leaves with symptoms of pear curl. J. Am. Soc. Hort. Sci., 100, 184-187, 1975.

D'Agostino G., and Pennazio S.: An ultrastructural study of the senescence induced in Gomphrena globosa leaves by mineral deficiency. J. Submicrosc. Cytol., 13, 373-383, 1981.

D'Agostino G., and Pennazio S.: Fine structure of necrotic lesions induced by tobacco necrosis virus in tobacco. J. Submicrosc. Cytol., 17, 229-237, 1985.

D'Amato F.: Chromosome endoreduplication in plant tissue development and function. In: Plant Cell proliferation and its Regulation in Growth and Development. (Eds. Bryant J.A. and Chiatante D.), Kluwer Academic Publishers, The Netherlands, pp. 153-166, 1998.
Fusconi A., Sampò S., Lingua G., Gnavi E., and Berta G.: Ploidy in tomato roots and its variations induced by Glomus mosseae and Phytophthora nicotianae var. parasitica. Atti dell'Accademia dei Fisiocritici 26, 55-58, 1997.

Fusconi A., Gnavi E., Trotta A., and Berta G.: Apical meristems of tomato roots and their modifications induced by arbuscular mycorrhizal and soilborne pathogenic fungi. New Phytol., 142, 505-516, 1999.

Gendreau E., Hofte H., Grandjean O., Brown S., and Traas J. Phytochrome controls the number of endoreduplication cycles in the Arabidopsis thaliana hypocotyl. Plant J., 13 , 221-230, 1998.

Grif V.G.: Some aspects of plant karyology and karyosystematics. In: International Review of cytology. A survey of cell biology (Ed. Jeon K.W., Academic Press, San Diego), 196, pp. 131-169, 2000.

Isaac S.: Fungal-plant interactions. Chapman \& Hall, London, New York, 1992.

Lepka P., Stitt M., Moll E., and Seemüller.: Effect of phytoplasmal infection on concentration and translocation of carbohydrates and amino acids in periwinkle and tobacco. Phys. Mol. Plant Pathol., 55, 59-68, 1999.

Lee I.M., Gundersen-Rindal D.E., Davis R.E., and Bartoszk I.: Revised classification scheme of phytoplasmas based on RFLP analyses of 16SrRNA and ribosomal protein gene sequences. Int. J. Syst. Bacteriol., 4, 1153-1169, 1998.

Lherminier J., and Boudon-Padieu E.: In situ detection of grapevine flavescence dorée phytoplasmas and their infection cycle in experimental and natural host plants. In: Histology, Ultrastructure and Molecular Cytology of Plant Microorganism Interactions, (Eds. Nicole M. and Gianinazzi-Pearson V.) Kluwer Academic Publishers, The Netherlands, pp. 245-255, 1996.

Lingua G., Varese G.C., Trotta A., Fusconi A., Gnavi E., and Berta G.: Flow cytometry as a tool to investigate nuclear senescence in symbiotic and pathogenic systems. Agronomie, 16, 663-670, 1996.

Lingua G., Fusconi A. and Berta G.: The nucleus of differentiated root plant cells: modifications induced by arbuscular mycorrhizal fungi. Eur. J. Histochem. 2001. 
Lisa V., Lovisolo O., D’Agostino G., Loche P. and Fresu B.: Grave malattia del pomodoro associata a micoplasmi, in Sardegna. Atti Giornate Fitopatologiche "Supplemento", 35 41, 1982.

Minucci C. and Boccardo G.: Genetic diversity in the stolbur phytoplasma group. Phytopath. Medit. 36, 45-49, 1997.

O'Brien I.E.W., Murray B.G., Baguley B.G., Morris B.A.M.,

Ferguson I.B.: Major changes in chromatin condensation suggest the presence of an apoptotic pathway in plant cells. Exp. Cell Res. 241, 46-54, 1998.

Pennell R.I. and Lamb C.: Programmed cell death in plants. Plant Cell 9, 1157-1168, 1997

Reynolds E.F.: The use of lead citrate at high $\mathrm{pH}$ as an electronopaque stain in electron microscopy. J. Cell Biol. 17, 2081963.

Sambrook J., Fritsch E.F., and Maniatis F.: Molecular Cloning, a laboratory manual. Second edition. Cold Spring Harbor Laboratory Press, 1989.
Sinclair W.A. and Griffiths H.M.: Detection of ash yellows mycoplasma like organisms in different tree organs and in chemically preserved specimens by a DNA probe vs. DAPI. Plant Desease 76, 2, 154-158, 1992.

Seemüller E., Marcone C., Lauer U., Ragozzino A. and Göschl M.: Current status of molecular classification of the phytoplasmas. J. Plant Pathol. 80, 3-26, 1998.

Traas J., Hulskamp M., Gendreau E., and Hofte H.: Endoreduplication and development: rule without dividing? Curr. Opinion Plant Biol. 1, 498-503, 1998.

Trotta A., Varese G.C., Gnavi E., Fusconi A., Sampò S., and Berta G.: Interactions between the soilborne root pathogen Phytophthora nicotianae var. parasitica. and the arbuscular mycorrhizal fungus Glomus mosseae in tomato plants. Plant Soil, 185, 199-209, 1996.

Woolhouse H.W.: Senescence in plant cells. In: Cell ageing and death, (Eds.Davies I. and Sigee D.C.), Cambridge University press, Cambridge, pp. 123-154, 1984. 